\title{
Analisis Kinerja Pelayanan Publik tentang Sumber Daya Manusia dan Responsivitas Pegawai di Kantor Kelurahan Kecandran Kecamatan Sidomukti Kota Salatiga
}

\section{Analysis of Public Service Performance on Human Resources and Employee Responsiveness at the Kecandran Village office, Sidomukti District, Salatiga City}

\author{
Muchamad Samsudin \\ Program Studi Magister Administrasi Publik, Fakultas Ilmu Sosial dan Ilmu Politik, \\ Universitas Diponegoro, Indonesia
}

Diterima: 12 Juni 2021; Direview: 02 Agustus 2021; Disetujui: 19 Agustus 2021

*Coresponding Email: udin325@gmail.com

\begin{abstract}
Abstrak
Artikel atau tulisan ini bertujuan untuk menganalisis kinerja pelayanan publik di Kelurahan Kecandran, Kecamatan Siomukti, Masalah difokuskan pada Analisa lebih mendalam terhadap kegiatan pelayanan publik di Kelurahan Kecandran dan menelaah bentuk responsivitas yang di lakukan pegawai serta pihak terkait dalam pelayanan tersebut. Guna mendekati masalah ini dipergunakan acuan teori dari Nicholas Henry (dalam Suwitri, 2011), Carl Van Horn dan Donal Van Meter, 1975. Data-data dikumpulkan melalui metode penelitian deskriptif melalui kegiatan observasi lapangan, data primer dan sekunder dan wawancara, dan dianalisis secara kualitatif. Kajian ini menyimpulkan bahwa perlunya melakukan penelitian terkait analisis kinerja pelayanan publik di kantor kelurahan Kecandran, Kecamatan Sidomukti yang lebih mendalam terhadap sumber daya Manusia serta responsivitas.

Kata Kunci: Kinerja Pelayanan Publik; Penyelenggaraan Pelayanan; Kepuasan Masyarakat.
\end{abstract}

\begin{abstract}
This article or writing aims to provide an effective understanding of the analysis of the performance of public services in Kecandran Village, Siomukti District, the problem is focused on a more in-depth analysis of public service activities in Kecandran Village and examine the form of responsiveness carried out by employees and related parties in the service. In order to approach this problem, Nicholas Henry's theoretical reference is used (in Suwitri, 2011), Carl Van Horn dan Donal Van Meter, 1975. The data were collected through descriptive research methods through field observations, primary and secondary data and interviews, and analyzed qualitatively. This study concludes that it is necessary to conduct research related to the analysis of the performance of public services at the Kecandran sub-district office, Sidomukti District which is more in-depth on human resources and responsiveness.
\end{abstract}

Keywords: Public Service Performance; Service Delivery; Community Satisfaction.

How to Cite: Samsudin, M., (2021), Analisis Kinerja Pelayanan Publik tentang Sumber Daya Manusia dan Responsivitas Pegawai di Kantor Kelurahan Kecandran Kecamatan Sidomukti Kota Salatiga, Journal of Education, Humaniora and Social Sciences (JEHSS), 4(2): 1028-1034.

Wwit http://mahesainstitute.web.id/ojs2/index.php/jehss




\section{PENDAHULUAN}

Pelaksanaan otonomi daerah adalah pemerintahan Kabupaten/Kota dengan lingkup pemerintahan terkecil adalah Kelurahan. Berdasarkan Peraturan Pemerintah Republik Indonesia Nomor 73 Tahun 2005 tentang Kelurahan, mengamanatkan pemberian otonomi luas kepada daerah yang diarahkan untuk mempercepat terwujudnya kesejahteraan masyarakat melalui peningkatan pelayanan, pemberdayaan, dan peran serta masyarakat.

Pemerintah berusaha memberikan upaya untuk meningkatkan pelayanan terhadap publik/masyarakat, pembenahan dalam penyelenggaraan pemerintah yang berorientasi pada fungsi pelayanan masyarakat, hendaknya di titikberatkan atau dimulai dari lini terbawah yaitu pada pemerintah desa/kelurahan, karena desa/kelurahan merupakan pelayanan yang paling dekat dan mudah di jangkau oleh masyarakat dan merupakan pelaksanaan pelayanan kepada masyarakat garda terdepan. Perbaikan dalam penyelenggaraan pemerintahan kelurahan harus dilakukan, terutama bagaimana menumbuhkan dan meningkatkan kinerja aparat kantor kelurahan sebagai abdi negara dan abdi masyarakat yang mau tidak mau harus berupaya meningkatkan kemampuan kerjanya semaksimal mungkin, karena pelaksanan tugas pelayanan oleh pemerintah kelurahan sangat tergantung pada kinerja aparatnya. Sedangkan masyarakat hanya dapat menilai kinerja kantor kelurahan dari kualitas pelayanan yang diterimanya. Tuntutan ini kemudian direspon oleh pemerintah dengan melakukan berbagai upaya yang mengarah pada terciptanya peningkatan kualitas pelayanan publik pada semua bidang, bahkan pelayanan publik dijadikan sebagai salah satu agenda terbesar dalam orientasi kebijakan pemerintah saat ini. Meskipun upaya tersebut telah dilakukan oleh pemerintah, namun realitas pelayanan publik belum juga menunjukkan perubahan yang signifikan. Banyaknya keluhan dan pengaduan dari masyarakat menunjukkan bahwa kualitas pelayanan publik sangat rendah. Pengaduan dan keluhan tentang prosedur pelayanan yang berbelit, tidak adanya kepastian dan jangka waktu penyelesaian, biaya yang sangat mahal, persyaratan yang tidak transparan, sikap petugas pelayanan yang kurang responsif sering ditemui dan hampir merata dalam semua bidang pelayanan pemerintah saat ini (Surjadi, 2012).

Peningkatan kualitas pelayanan yang menjadi tuntutan masyarakat harus di penuhi oleh aparat kelurahan sebagai penyelenggara pemerintah di kelurahan. Karena pada dasarnya menerima pelayanan yang memuaskan dari aparat pemerintah merupakan hak yang dimiliki setiap warga masyarakat. Dengan pelayanan yang diterima tersebut maka diharapkan masyarakat akan berpartisipasi aktif dalam mendukung tugas-tugas aparat pemerintah, sehingga terjadi keseimbangan antara hak yang ditetapkan oleh masyarakat dan kewajiban yang harus dijalankan sebagai warga negara. Pelayanan yang diberikan tanpa memandang status, pangkat, dan golongan dari suatu masyarakat. Pada saat yang sama masyarakat mempunyai hak yang sama untuk memperoleh pelayanan tersebut dengan landasan yang bersifat umum dalam bentuk pedoman tata laksana pelayanan umum.

Berkaca dari permasalahan pelayanan publik maka diperlukan peningkatan kinerja pelayanan publik yang jujur, adil, tanpa pandang bulu dan berorientasi pada kebutuhan masyarakat. Pelayanan publik menjadi hal sangat penting mengingat bahwasanya tugas utama dari pegawai di instansi pemerintah adalah melayani masyarakat dengan setulus hati dan iklas dengan tidak memanfaatkan jabatan dan wewenang yang diamanahkan. Sehingga untuk mendalami permasalahan terkait pelayanan publik yang di lakukan oleh instansi pemerintah maka fokus penelitian ini lebih kepada kinerja pelayanan publik.

Semakin berkembangnya kesadaran masyarakat dalam mendapatkan hak pelayanan publik yang berkualitas, maka pemerintah dituntut meningkatkan kinerja yang baik dalam memberikan pelayanan publik kepada masyarakat.

Di dalam Undang-undang Nomor 23 tahun 2014 tentang Pemerintahan Daerah pasal 229 menjelaskan bahwa Kelurahan dibentuk dengan Peraturan Daerah Kabupaten/Kota dengan berpedoman pada Peraturan Pemerintah. Kelurahan dipimpin oleh seorang kepala Kelurahan yang disebut Lurah selaku perangkat Kecamatan dan bertanggung jawab kepada Camat. Lurah diangkat oleh Bupati/Wali Kota atas usul Sekretaris Daerah dari pegawai negeri sipil yang 
memenuhi persyaratan sesuai dengan ketentuan peraturan perundang-undangan, serta bertugas membantu Camat dalam banyak hal termasuk di dalamnya bidang pemerintahan dan pelayanan masyarakat. Kelurahan memiliki posisi yang strategis sebagai representasi kinerja Pemerintah Daerah yang bersentuhan langsung dengan masyarakat. Baik atau buruk, cepat atau lambatnya pelayanan secara langsung dapat dirasakan masyarakat. Citra birokrasi pemerintahan secara keseluruhan akan banyak ditentukan oleh kinerja dari Kelurahan.

Dalam Peraturan Pemerintah Republik Indonesia Nomor 96 Tahun 2012 Tentang Pelaksanaan Undang-Undang Nomor 25 Tahun 2009 Tentang Pelayanan Publik pada Pasal 1 Ayat (1), Ayat (2), dan Ayat (3) disebutkan bahwa Pelayanan Publik adalah kegiatan atau rangkaian kegiatan dalam rangka pemenuhan kebutuhan pelayanan sesuai dengan peraturan perundangundangan bagi setiap warga negara dan penduduk atas barang, jasa, dan/atau pelayanan administratif yang disediakan oleh penyelenggara pelayanan publik (Ayat 1). Penyelenggara Pelayanan Publik yang selanjutnya disebut Penyelenggara adalah setiap institusi penyelenggara negara, korporasi, lembaga independen yang dibentuk berdasarkan Undang-Undang untuk kegiatan pelayanan publik, dan badan hukum lain yang dibentuk semata-mata untuk kegiatan pelayanan publik (Ayat 2). Pelaksana Pelayanan Publik yang selanjutnya disebut Pelaksana adalah pejabat, pegawai, petugas, dan setiap orang yang bekerja di dalam organisasi penyelenggara yang bertugas melaksanakan tindakan atau serangkaian tindakan pelayanan publik (Ayat 3).

Berdasarkan hasil penelitian Meylisa Thesa Walukow, Mieke Roring, Johny R.E Tampi (2016), mengatakan bahwa pelatihan sumber daya manusia berpengaruh signifikan terhadap produktivitas kerja. Sedangkan menurut Matutina (2001), kualitas kerja mengacu kepada kualitas sumber daya manusia, sedangan kualitas sumber daya manusia mengacu kepada pengetahuan (knowledge), keteramplilan (skill), dan kemampuan (abilities). Dengan meningkatnya kualitas sumber daya manusia yang dimiliki organisasi dapat dijadikan sebagai penyangga dan penggerak roda organisasi untuk mewujudkan visi, misi dan tujuan organisasi itu sendiri (Azhar, 2007). Tanggung jawab kualitas sumber daya manusia sudah dilakukan oleh lembaga pengembangan teknologi informasi komputer yang hanya memberikan pelatihan teknis saja, seharusnya juga memberikan pelatihan pelayanan prima kepada pengelola Information and Communications Technology. Pelatihan pelayanan prima mempunyai tujuan untuk meningkatkan kemampuan pejabat dan pegawai di lingkungan Kelurahan Kecandran Kecamatan Sidomukti Kota Salatiga yaitu Lurah, Sekretaris Kelurahan, Kasi Pemerintahan, Ketentraman dan Ketertiban Umum, Kasi Ekonomi dan Pembangunan dan Kasi Sosial dan Pemberdayaan Masyarakat dalam memberikan pelayanan prima kepada masyarakat.

Tujuan dalam penelitian ini adalah untuk menganalisis Kinerja Pelayanan Publik di Kantor Kelurahan Kecandran Kecamatan Sidomukti Kota Salatiga dan untuk menganalisis faktor yang mempengaruhi Kinerja Pelayanan Publik di Kantor Kelurahan Kecandran Kecamatan Sidomukti Kota Salatiga.

\section{METODE PENELITIAN}

Tiap penelitian memerlukan perencanaan, sehingga dibutuhkan suatu desain penelitian. Untuk itu dalam rangka menganalisis kinerja pelayanan publik di Kantor Kelurahan Kecandran Kecamatan Sidomukti Kota Salatiga, penulis menggunakan tipe penelitian deskriptif, dengan mengkombinasikan pendekatan kualitatif, analisis data sekunder dan wawancara mendalam secara langsung (Indepth Interview) untuk menggali data-data primer. Penelitian deskriptif dapat diartikan sebagai prosedur pemecahan masalah yang diselidiki dengan menggambarkan/melukiskan keadaan subyek/obyek penelitian (seorang, lembaga, masyarakat dan lain-lain) pada saat sekarang berdasarkan fakta-fakta yang tampak atau sebagaimana adanya (Nawawi ,1998). Penelitian deskriptif ini akan dipadukan dengan pendekatan kualitatif.

Dari sisi sumber datanya, penelitian yang dilakukan ini lebih menekankan pada penelitian lapangan (field study). Penelitian lapangan ini, meliputi kegiatan observasi lapangan, wawancara dengan responden biasa dan responden kunci untuk memperoleh data primer. Sedangkan studi kepustakaan dimaksudkan untuk mendapatkan teori dan konsep-konsep yang diperlukan sebagai 
landasan dasar dan kegiatan ini meliputi studi terdapat data sekunder yang ada. Fokus peneliti pada penelitian ini adalah Analisis Kinerja Pelayanan Publik di Kantor Kelurahan Kecandran Kecamatan Sidomukti Kota Salatiga, dimana penelitian ini menganalisis bagaimana kinerja pelayanan publik di kantor kelurahan Kecandran dalam memberikan pelayanan sesuai dengan kebutuhan masyarakat dengan memperhatikan indikator pelayanan publik. Lokus penelitian ini adalah Kelurahan Kecandran Kecamatan Sidomukti Kota Salatiga. Penentuan fokus dan lokus penelitian dilakukan untuk mempersempit ruang lingkup penelitian dan pembahasan agar tujuan dari penelitian dapat tercapai dengan baik.

\section{HASIL DAN PEMBAHASAN}

Perhatian terhadap pelayanan pada Kelurahan Kecandran Kecamatan Sidomukti Kota Salatiga merupakan jawaban untuk meningkatkan kualitas pelayanan publik, agar terwujudnya pelayanan yang baik dan bersih (good governance). Dengan memberikan perhatian berupa Analisa dan melakukan penilaian/evaluasi terhadap pelayanan yang dilakukan sehingga terwujudnya tata kelola pelayanan di Kelurahan Kecandran Kecamatan Sidomukti Kota Salatiga untuk melaksanakan good government yang transparan, professional dan akuntabel. Pelayanan publik tersebut mempunyai tujuan untuk menunjang kepuasan masyarakat yang terlayani. Terdapat berbagai faktor yang mempengaruhi (responsivitas) atau menunjang pelayanan yang baik, salah satunya yaitu sumber daya manusia.

Sumber daya manusia yang berkualitas merupakan modal dasar dalam pengelolaan teknologi informasi yang berpengaruh terhadap hasil kinerja institusi. Sumber daya yang berkualitas diperoleh dari pengembangan sumber daya manusia itu sendiri oleh organisasi dengan rencana yang dimilikinya. Pengembangan sumber daya manusia dapat dilakukan dengan jalan pendidikan formal dan pendidikan non formal seperti melalui jalur latihan kerja dan jalur pengembangan di tempat kerja, penerapan belajar dalam organisasi, dan pengembangan berbasis kompentensi (Ruhana, 2012).

Kualitas sumber daya manusia adalah kemampuan dari pegawai menjalankan tugasnya dalam memberikan pelayanan terhadap masyarakat yang dilihat dari kemahiran, latar belakang pendidikan, dan profesional dalam menjalankan tugas.

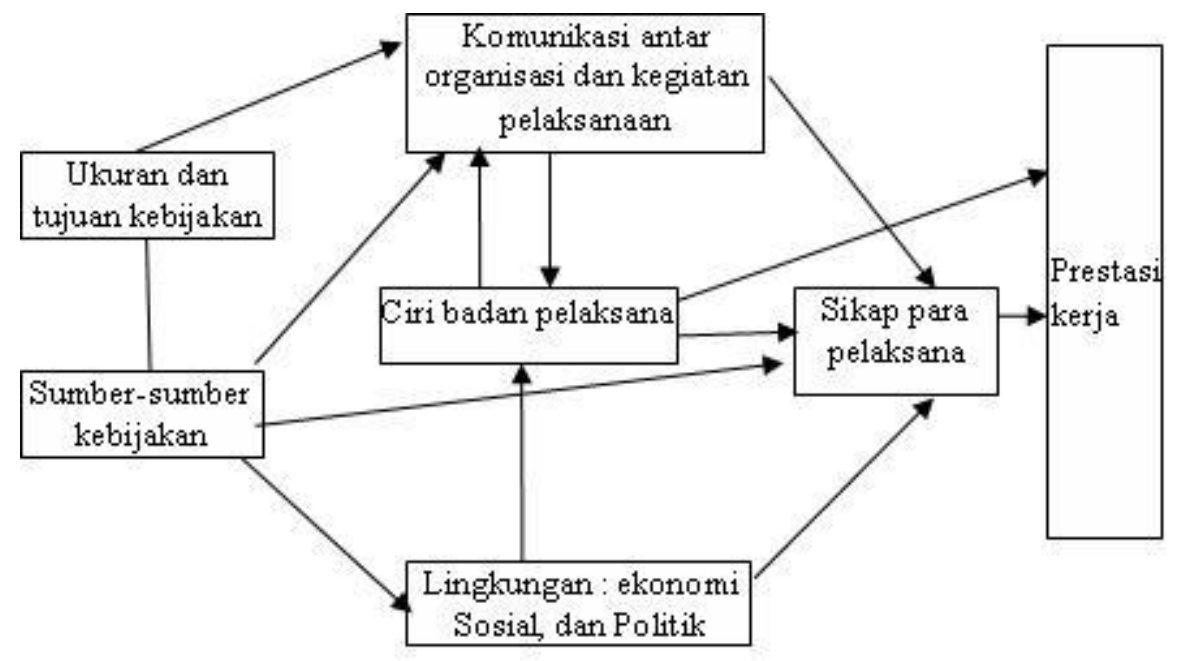

Gambar 1. Model A Policy Implementation Process, Carl Van Horn dan Donal Van Meter (1975)

Secara deskriptif potensi pelayanan publik di Kelurahan Kecandran Kecamatan Sidomukti Kota Salatiga sudah memenuhi syarat administrasi untuk melakukan pekerjaannya, tetapi secara aktual pengelola belum cukup, karena kompleknya masalah yang dihadapi dalam pengelolaan pemberkasan dan pelayanan. Untuk mengahadapinya pengelola menambah wawasan dengan 
mengikuti pelatihan agar dapat memberikan kinerja yang baik, efektif dan efisien. Dengan pendidikan formal saja tidak cukup untuk mengelola sistem aplikasi pelayanan tersebut, karena pengelolaannya juga memerlukan keterampilan lainnya. Untuk meningkatkan keterampilan sumber daya manusia pengelola sistem aplikasi pelayanan dapat dilakukan dengan pendidikan non formal atau lebih sering disebut pelatihan (training) baik teknis maupun non teknis. Pelatihan teknis dimaksud untuk dapat menyelesaikan masalah teknis, sedangankan pelatihan non teknis seperti halnya pelatihan pelayanan prima dimaksud untuk dapat memberikan pelayanan yang sesuai dengan harapan pengguna. Sumber daya manusia sangat penting dan berpengaruh dalam menggerakkan suatu kebijakan yang telah ditetapkan (Carl Van Horn dan Donal Van Meter, 1975).

Selain pelatihan (training) dapat juga dengan memberikan insentif atau bonus untuk dapat meningkatkan kualitas kerja (performance quality) dalam penggunaan teknologi informasi, sehingga dapat meningkatkan efesiensi dan efektifitas kerja (Bitner dan Zeithaml, dalam Riorini, 2004). Nasution (1994) mengatakan bahwa insentif program yang ditujukan untuk merangsang karyawan untuk meningkatkan kinerjanya. Insentif atau bonus yang diterima oleh karyawan dapat dibagi atas 2 (dua), yaitu: (1) financial, yaitu imbalan yang diberikan kepada karyawan dalam bentuk gaji, bonus dan lainnya yang sejenis yang diberikan oleh perusahaan, (2) non financial, yaitu imbalan yang diberikan kepada karyawan untuk menciptakan kondisi yang menyenangkan dalam lingkungan kerjanya, seperti rekreasi, menyediakan fasilitas cafeteria dan tempat ibadah (Husen, 1999). Pengembangan sumber daya manusia merupakan tuntutan tugas dalam menjawab tantangan masa depan dalam mencapai profesionalisme kerja dan meningkatkan produktifitas. Untuk mencapainya diperlukan pendidikan dan pelatihan yang dilakukan untuk pegawai lama maupun pegawai baru dalam rangka meningkatkan pengetahuan mereka tentang teknologi informasi yang semakin berkembang, guna bekerja secara smart, efektif dan efisien. Pelatihan yang dilakukan harus mendapat manfaat langsung bagi pengelola teknologi informasi, bagi pegawai dan staff Kelurahan sehingga terarah kepada peningkatan kemampuan dan keahlian sumber daya yang berkaitan dengan fungsi dan tanggung jawab individu yang bersangkutan. Pelatihan menurut Ivancevich (2008) adalah suatu proses yang sistematis yang dilakukan untuk mengubah prilaku seseorang, sehingga dapat meningkatkan kinerja organisasi. Pelatihan yang dilakukan adalah yang berorientasi ke masa sekarang dan dapat membantu dalam penguasaan keterampilan serta kompentensi spesifik untuk mencapai keberhasilan dalam pekerjaannya. Artinya dengan pelatihan dapat melakukan perubahan yang sistematis, skill, attitude dan behavior seseorang, sehingga dapat terwujudnya sasaran yang ingin dicapai oleh suatu organisasi.

Baik buruknya efesiensi maupun efektivitas organisasi tergantung terhadap pengembangan sumber daya manusia organisasi itu sendiri. Artinya organisasi secara proporsional harus memberikan pendidikan dan pelatihan yang sebaik-baiknya atau sesempurna mungkin. Pelatihan teknis masih sangat rendah terserap oleh pegawai di Kelurahan Kecandran Kecamatan Sidomukti Kota Salatiga , hal tersebut di jelaskan oleh responden yaitu pegawai di Kelurahan tersebut, berikut adalah penjelasannya: " Karena di Bkdiklatda (Badan Kepegawaian dan Diklat Daerah) kota Salatiga anggaran untuk pelaksanaan Diklat/pelatihan sudah banyak terserap pada Diklat prajab/diksar Diklat kepemimpinan serta Diklat teknis fungsional, yg biasanya Diklat teknis fungsional sudah di gunakan oleh dinas ${ }^{2}$ teknis Badan serta lingkup pengambil kebijakan (Setda)". Hal tersebut menjadikan Kelurahan belum bisa merasakan wujud dari Pengembangan karir berupa pelatihan yang sangat penting guna menunjang kinerja pegawai.

Kualitas merupakan tingkat keunggulan yang diharapakan dapat memenuhi keinginan pelanggan (Wyckof dalam Lovelock, 1997). Dengan pelayanan yang berkualitas dapat meningkatkan kepuasan yang diterima oleh pengguna layanan. Kepuasan masyarakat merupakan ukuran kesuksesan dari pengelolaan dan pelayanan yang dilakukan, karena cermin dari kepuasan pengguna adalah seberapa jauh mereka percaya terhadap sistem informasi yang disediakan dapat memenuhi kebutuhan dan harapan mereka (Guimaraes, et al., 2003). Kepuasan/responsivitas dari penerima layanan yaitu masyarakat tercapai tidak hanya dalam hal teknis saja, tetapi juga tanggungjawab dari petugas pemberi layanan dalam memberikan pelayanan terhadap masyarakat. 
Berdasarkan hasil wawancara yang dilakukan dengan masyarakat penerima layanan, mereka cukup puas dengan kemampuan petugas dalam menyelesaikan masalah teknis yang dihadapinya, tetapi kurang puas dengan pelayanan yang diterima dari petugas. Tujuan peningkatan layanan publik adalah untuk memperoleh nilai tambah yang dapat menjadi solusi dalam memberikan pelayanan yang baik, tetapi belum sepenuhnya dapat menjamin kesuksesan pelayanan yang diberikan oleh institusi. Hal ini disebabkan oleh petugas yang mengelola sistem informasi akademik di Kelurahan Kecandran Kecamatan Sidomukti Kota Salatiga kurang mampu memberikan pelayanan yang sesuai dengan harapan masyarakat, bahwa petugas sering tidak berada dalam ruangan waktu jam kerja dikarenakan kurang baiknya pendistribusian jobdesk lain, tetapi kurang disiplinnya petugas menjadi salah satu faktor yang mengganggu pelayanan terhadap masyarakat, karena efektifitas pelayanan administrasi dapat dilihat dari perilaku petugas yang mengelola atau menangani pelayanan terhadap masyarakat. Terganggunya pelayanan kepada masyarakat dapat menjadi image yang kurang baik terhadap institusi sendiri. Untuk itu perlu ditingkatkan disiplin petugas yang mengelola sistem aplikasi pelayanan, sehingga dapat dilakukan perbaikan kualitas pelayanan, kualitas sumber daya manusia pengelola dan kinerja organisasi. Dengan melakukan perbaikan diharapkan dapat meningkatkan kepercayaan dan kepuasan masyarakat terhadap kualitas pelayanan publik yang mereka terima.

Mengatasi keluhan dari masyarakat terhadap kinerja pelayanan atau pengelola di Kelurahan Kecandran Kecamatan Sidomukti Kota Salatiga maka sudah melakukan antisipasi dengan menggunakan alat canggih untuk sistem absensi, sehingga dapat dengan akurat mendeteksi kehadiran staff atau pegawai, yaitu dengan menggunakan absensi sensor wajah. Hal ini dilakukan untuk meningkatkan kehadiran dan tanggung jawab pegawai dalam melaksanakan tugasnya. Dengan kehadiran yang tepat waktu diharapkan dapat meningkatkan disiplin sehingga dapat meningkatkan kinerja. Faktor lain yang digunakan untuk meningkatkan disiplin kerja pegawai, yaitu: (a) disiplin preventif, yaitu tindakan yang dilakukan untuk mendorong pegawai mentaati peraturan yang berlaku agar tidak terjadi pelanggaran. Sifatnya adalah mencegah agar terciptanya disiplin diri pegawai, (b) disiplin korektif, yaitu tindakan pencegahan agar tidak terulang lagi pelanggaran. Tujuannya adalah memperbaiki perilaku yang melanggar aturan dan melakukan pencegahan terhadap pelanggaran yang saman, dan (c) disiplin progresif, yaitu memberikan kesempatan untuk memperbaiki diri kepada pegawai yang melakukan pelanggaran, sehingga tidak akan mengulangi perbuatannya lagi serta mendapatkan sanksi yang lebih berat apabila terulang kembali (Hariandja, 2002).

Disamping itu untuk mengatasi keluhan masyarakat tersebut, Lurah sebagai pejabat yang berwenang di Kelurahan Kecandran Kecamatan Sidomukti Kota Salatiga harus menegakkan peraturan yang sesuai dengan undang-undang yang berlaku. Artinya pegawai/staff dengan status pegawai negeri sipil yang melanggar aturan dapat diberikan sangsi adminstrasi, hal ini sesuai dengan Peraturan Pemerintah Nomor 53 Tahun 2010 tentang Disiplin Pegawai. Sedangkan kepada pegawai/staff yang berstatus non pegewai negeri sipil dapat diberikan teguran dengan surat peringatan (SP). Apabila pelanggaran tersebut berulang kembali, pimpinan/Lurah harus menindaknya lebih hukuman yang lebih berat. Karena berdasarkan hasil penelitian yang dilakukan oleh Muhammad Johan, dkk (2016), mengatakan bahwa faktor kepemimpinan, kompensasi, dan budaya organisasi berpengaruh terhadap disiplin kerja serta hukuman disiplin tidak berpengaruh terhadap disiplin kerja. Meningkatkan disiplin juga harus diikuti dengan sosialisasi budaya organisasi, karena sosialisasi memperkenalkan tentang tujuan, strategi, nilainilai, dan standar perilaku organisasi serta informasi yang berkaitan dengan pekerjaan kepada karyawan. Penelitian yang dilakukan oleh Nurtjahjani dan Masreviastuti (2007), mengatakan bahwa budaya organisasi dapat berfungsi secara optimal dengan proses sosialisasi agar dapat dipahami oleh karyawan. Dengan dipahaminya budaya organisasi dan tegaknya disiplin pengelola dan pelayanan Kelurahan Kecandran Kecamatan Sidomukti Kota Salatiga, sehingga dapat terwujud pelayanan yang sesuai dengan harapan masyarakat dan dapat meningkatkan kepuasan masyarakat. 


\section{SIMPULAN}

Kelurahan Kecandran Kecamatan Sidomukti Kota Salatiga dikelola oleh pegawai/staff yang memiliki latar belakang pendidikan SMA, Diploma-III sampai dengan Strata-1. Dengan latar belakang pendidikan tersebut, sumbar daya manunjang pengelolaan dan pelayanan kepada masyarakat seharusnya mampu untuk mengatasi kendala teknis dan permasalahan yang dihadapi oleh masyarakat, tetapi kurang mampu memberikan pelayanan yang sesuai dengan harapan masyarakat (pelayanan prima). Kelurahan Kecandran Kecamatan Sidomukti Kota Salatiga masih belum terjangkau untuk menerima pelatihan guna menunjang kinerja pegawai/staff. Kelurahan Kecandran Kecamatan Sidomukti Kota Salatiga menggunakan sensor wajah untuk mendeteksi kehadiran pegawai/staff dengan tujuan untuk meningkatkan displin dan kinerja. Penggunaan sensor wajah masih kurang optimal untuk meningkatkan disiplin pengelola dan pelayanan di Kelurahan Kecandran Kecamatan Sidomukti Kota Salatiga. Sesuai dengan informasi masyarakat petugas pengelola dan pelayanan kurang disiplin dalam melaksanakan tugas, karena petugas sering meninggalkan ruangan waktu jam kerja. Hal ini jelas mengganggu aktifitas pelayanan masyarakat.

\section{DAFTAR PUSTAKA}

Van Horn, C., dan Van Meter, D., (1975). Model-model Dalam Kebijakan Implementasi. Yogyakarta

Nawawi, H., (1998). Metode Penelitian Bidang Sosial. Yogyakarta:Gadjah Mada University Press.

Hariandja, M.T.E. (2002). Manajemen Sumber Daya Manusia. Jakarta : Grasindo

Husein, Umar. (1999). Manajemen Sumber Daya Manusia Dalam Organisasia. Jakarta: Gramedia Pustaka Utama.

Ivancevich, J.M., (2008). Perilaku dan Manajemen Organisasi. Jakarta : Erlangga.

Matutina. (2001). Manajemen Sumber Daya Manusia. Jakarta : Gramedia Widia Sarana Indonesia.

Walukow, M. T., Roring, M., \& Tampi, J. R. (2016). Pengaruh Pelatihan Sumber Daya Manusia Terhadap Produktivitas Kerja Karyawan Pada Pt Pln (Persero) Wilayah Suluttenggo Area Manado. Jurnal Administrasi Bisnis (Jab), 4(4).

Widikusyanto, M. J., Nafiudin, N., Wibowo, H. A., \& Marwan, J. (2016). Faktor-Faktor Yang Memengaruhi Disiplin Kerja Dan Dampaknya Terhadap Kinerja Aparatur Sipil Negera Pemerintah Provinsi Banten. Sains Manajemen, 2(2).

Nasution, M. (1994). Manajemen Personalia: Aplikasi dalam Perusahaan. Djambatan, Jakarta.

Nurtjahjani, F. Masreviastuti, (2007), Analisa Pengaruh Budaya Organisasi terhadap Kepuasan Kerja dan Pengaruhnya pada Kinerja Karyawan, Arthavidya, 8(1), 155-162.

Riorini, S.V., (2004). Quality Performance dan Komitmen Organisasi. Jurnal Media Riset Bisnis dan Manajemen.

Surjadi. (2012). Pembangunan Kinerja Pelayanan Publik. Bandung: PT. Refika.

Keputusan Menteri Pendayagunaan Aparatur Negara Nomor 25/M.PAN/2/2004.

Undang-undang Nomor 23 tahun 2014 tentang Pemerintahan Daerah pasal 229

Peraturan Pemerintah Nomor 53 Tahun 2010 tentang Disiplin Pegawai.

Peraturan Pemerintah Republik Indonesia Nomor 96 Tahun 2012 Tentang Pelaksanaan Undang-Undang Nomor 25 Tahun 2009 Tentang Pelayanan Publik pada Pasal 1 Ayat (1), Ayat (2), dan Ayat (3).

Ruhana, I. (2012). Pengembangan Kualitas Sumber Daya Manusia vs Daya Saing Global. PROFIT: Jurnal Administrasi Bisnis, 6(1). 